\title{
LITERATURE OF THE AMERICAS IN THE MAKING: U.S. WRITERS AND TRANSLATION IN SUR, 1931-1944
}

\author{
Gorica Majstorovic \\ Gorica. Majstorovic@stockton.edu \\ The Richard Stockton College of New Jersey
}

\begin{abstract}
This essay engages history of translation by examining one of its most important contributors: Sur, a literary journal that Victoria Ocampo ran for 45 years and 340 issues. The most celebrated Latin American writers of the 1960s 'Boom' unanimously recognized that their key literary influences were those that they had first read in translation in Sur. Specifically, the essay focuses on the translations of North American literature in Sur's early years: E. Hemingway, M. Twain, L. Hughes, K. A. Porter, E. A. Poe, H. Melville, e. e. cummings, W. Whitman, H. James, and most prominently, W. Faulkner, are translated by J. L. Borges, E. Pezzoni, J. Bianco, R. Baeza, BioyCasares, and M. Acosta. While highlighting the task of translators as crucial cultural intermediaries, the essay analyzes the subsequent construction of inter-American relations and ways in which Sur (1931-1976) conceived a peculiar version of cosmopolitanism.
\end{abstract}

\section{Resumen}

El presente ensayo aborda la historia de la traducción al examinar uno de sus contribuidores más importantes: Sur, la revista literaria que Victoria Ocampo dirigió por 45 años y 340 números. Los escritores latinoamericanos más célebres de la generación del 'Boom' unánimemente reconocen que las influencias literarias claves eran las que leyeron primero en traducción en Sur. En términos específicos, el ensayo se enfoca hacia las traducciones de la literatura norteamericana en la época temprana de Sur: E. Hemingway, M. Twain, L. Hughes, K. A. Porter, E. A. Poe, H. Melville, e. e. cummings, W. Whitman, H. James, y más prominentemente, W. Faulkner, que fueron traducidos por J. L. Borges, E. Pezzoni, J. Bianco, R. Baeza, Bioy Casares y M. Acosta. Al tiempo que señala la labor de los traductores como intermediarios culturales de 
suma importancia, el ensayo analiza la subsiguiente construcción de las relaciones interamericanas y las maneras en las que Sur (1931-1976) concibe una versión peculiar del cosmopolitismo.

Keywords: Translation. Cosmopolitanism. Inter-American. Victoria Ocampo. Sur.

Palabras clave: Traducción. Cosmopolitismo. Interamericano. Victoria Ocampo. Sur.

Manuscript received on June 20, 2012 and accepted on October 5, 2012. 
While several studies have examined cultural bonds between Europe and Latin America in Sur, North American literature and the subsequent constructions of inter-American relations and Literature of the Americas have been unsufficiently explored in the context of this literary journal. In this light, the present essay addresses Victoria Ocampo's role as a translator, editor, and international cultural broker who made a significant impact on Spanish American culture and its relationship to writings in English-U. S. literature in particular. I have studied the importance of Ocampo for the construction of hemispheric alliances and cultural ties between North and South America in my 2005 essay "An American Place: Victoria Ocampo's Editorial Politics, the Foundation of Sur, and Hemispheric Alliances". Here, I bring to the forefront the importance of Victoria Ocampo for Translation Studies and more specifically, I discuss her prominent role in the history of translation, by examining ways in which Ocampo's journal Sur and its homonymous publishing house shaped the construction of inter-American cultural relations from 1931 to 1944.

In 1931 Victoria Ocampo founded Sur, a literary journal that she ran for 45 years and 340 issues. The far-reaching cultural enterprise that Sur would become, started with a conflict between an Argentine-Americanist editorial vision and pronounced European sympathies that were reflected in Ocampo's choice of the language in which to write. She wrote first in French, as was expected for a woman of her social class, and subsequently translated into Spanish. The invitation to translate from French and English into Spanish, and to delve into the themes of the Latin American South, was then extended to the intellectuals from her social circles, both Argentine and foreign. I use the notion of 'hemispheric circulation', i. e. flowing in a cultural circuit North and South, in order to illustrate how Victoria Ocampo and her literary magazine Sur (1931-1976) conceived a modernist version of cosmopolitanism, which fused elite national culture, Americanism and selective internationalism.

Translation would remain at the core of Ocampo's cultural enterprise: it occupied a central role in the first years of Sur, and it continued to hold center stage in the later years. In 1976, two years before her death, Ocampo edited a penultimate volume of Sur (issue 338-339), entitled Problemas de 
la traducción ('Problems of Translation'). The volume itself was a translation of a 1971 PEN American Center edited collection, The World of Translation. In Ocampo's introductory essay to the collection, titled "Un asunto de suma importancia: la traducción” ('A Matter of Great Importance: Translation'), she claims that translation is a genuine part of Argentine culture. She thanks Jaime Rest for editing the volume and praises the excellent work of Argentine translators, while highlighting in particular Enrique Pezzoni's translation of Moby Dick, which she sees as a source of national pride: "Señalemos como algo excepcional y digno de orgullo nacional la díficil traducción de Moby Dick, de Enrique Pezzoni, que fue elogiada en el New York Times" ("We should note as something exceptional and worthy of national pride the difficult translation of Moby Dick by Enrique Pezzoni, which was praised in the New York Times') (Ocampo 1976: 16). This, and other scenes of translation, include cultural transactions that Sergio Waisman has described as "not only the results of the practice of translation (i. e. , the translated work), but also the moment of translation itself, a theorized space at which texts, cultures and readers intersect" (Waisman 2010-2011: 1).

The space of translation is conditioned through language 'contact zones' and it is defined as complex cultural intersection. Furthermore, translation is closely intertwined with the Argentine national project and its culture; during various historical junctures it has served as a source of cultural innovation, renovation, and ultimately, transformation. In this light, Waisman underscores translation as a prevalent practice in the development of Argentine literature, situated always at or near its core. He goes as far as to suggest that "to translate in Argentina, as history shows, is to write Argentina" (Waisman 2010-2011: 8).

Victoria Ocampo's first published text, Babel, emerged from translation. It was written in French and published in its Spanish translation in the Argentine daily La Nación in 1920. The Argentine-Spanish words in Ocampo were born of translation, first from French and then, as we will show later, from English as well. Yet it was only through the use of her 'transitory' Spanish that Ocampo would be allowed to "trespass", as it were, into the spheres of South American 'authenticity'. Moreover, this 'trespassing' gesture was significantly rebellious, as writing in French was both expected and socially accepted for a woman of her time and social status willing to write in Argentina. Paul Groussac, a French intellectual and the director of the Argentine National Library at the time, advised Ocampo to write in Spanish and only about personal matters. Groussac's advice for Ocampo is exemplary not only of the 
underestimation to which a Latin American writer, especially a woman, was subjected, but also of the male hegemony involved in every cultural matter of the time.

Translation was to be one of Ocampo's lifelong interests, to such a degree that Beatriz Sarlo has referred to the whole production of Ocampo's literary magazine Sur as 'a translation machine' (1998: 93). Translation, as a Sur-vival or the living after and beyond the life of the original text, as Walter Benjamin writes in his 1926 seminal essay on the task of a translator, is to be understood, Bella Brodzki points out, "not as an extension of life but as an infusion, a transfusion, of otherness" (1999: 207).

Since the founding of Sur in 1931, Victoria Ocampo was not only the main agent of this kind of cultural 'transfusion' into Latin America, but also a cosmopolitan 'bridge' between Argentine literary production and the rest of the world. Translation played a key role in this process. Sur greatly informed Latin American cultural circuits about literatura universal ('world literature'). Ocampo professed a life-long "fascination with the foreign" (Larkosh 2002: 99). The most celebrated Latin American writers of the so-called 1960s 'Boom' unanimously recognized that their key literary influences were those that they had first read in translation in Sur. No other literary journal in Spanish America, not even Vuelta, edited in Mexico by Octavio Paz, has reached the scope of influence that Sur has generated. Paz himself acknowledged in 1962 that what Ocampo accomplished, no one had ever achieved in Latin America (1962: 279).

Translation, as 'cultural transfusion' and 'cosmopolitan transmission', was cultivated primarily in Buenos Aires, where Sur was located, and to a lesser degree in other Argentine urban centers. "The space of the great modern city (a model which Buenos Aires approximated in the 20s and consolidated in the 30s) proposes itself as a stage for cultural crossings where, hypothetically, all meetings and loans are possible" (Sarlo 1993: 168). These cultural crossings, therefore, defined the urban modernity of Buenos Aires with a principle of heterogeneity. Sarlo describes this principle in a twofold way, as "una mala heterogeneidad" ('a bad heterogeneity') and "una heterogeneidad deseable" ('a desirable heterogeneity') (Sarlo 1996: 173). Both of these models of heterogeneity are defined with regard to their interdependencies on language and translation. And both of these interdependencies, as Sarlo argues, pointing to two contrasting writers, Victoria Ocampo and Roberto Arlt, are socially defined in the following way:

Una línea visible separa a los escritores que pueden leer (escribir, hablar, traducir) lenguas extranjeras de quienes están condenados a leer traducciones, 
como es el caso de Roberto Arlt. La relación con la lengua extranjera no responde a un esquema simple: por el contrario, en el caso de Arlt, un apellido centroeuropeo impronunciable, cómo él mismo tematiza cómicamente en una 'Aguafuerte', no le ha otorgado ni una lengua extranjera prestigiosa (ya que la lengua de origen fue traída por inmigrantes pobres y no por institutrices) ni la posibilidad de trabajar a partir del plurilingüismo. Arlt está anclado en malas traducciones y no puede ser traductor. Victoria Ocampo no lee traducciones sino originales y puede ser traductora o empresaria de traducciones. (Sarlo 1996: 174)1

The Latin American dissemination of modernist works and texts by U. S. writers in translation owes much to Victoria Ocampo and Sur. The first translations of William Faulkner in South America, to which we shall return in more detail, appeared in this journal in August 1939. Asked by Victoria Ocampo, its translator, Jorge Luis Borges, later translated Faulkner's novel The Wild Palms in 1940, under the title Palmeras salvajes. The celebrated Argentine author, who considered that translation was on a par with writing (and worked as a translator throughout his life), had already contributed his first translations to Sur: three poems by Langston Hughes that were published bilingually in the journal's third issue.

While examining the involvement of Sur in the creation of 'inter-American literature', to borrow a hyphenated term recently explored by Claudia Sadowski-Smith and Claire Fox, this essay draws on interdisciplinary critical work on Borges and translation, especially studies by Sergio Waisman and Efraín Kristal. Examining the role of translation in general, this essay also draws on earlier criticism, namely that of Emir Rodríguez Monegal, John King, and, more recently, Sylvia Molloy, Beatriz Sarlo, Ricardo Piglia, Christopher Larkosh, and Patricia Willson. While highlighting the international impact of Ocampo's work, this essay also recognizes the 23 years (1938-1961) that José Bianco dedicated to Sur, as editor and translator (of Henry James, among other writers).

1. 'A visible line separates the writers who can read (write, speak, translate) foreign languages from those who are forced to read translations, as is the case of Roberto Arlt. The relationship with a foreign language does not correspond to a simple diagram. On the contrary, in the case of Arlt, an unpronounceable Central European last name, as he himself comically describes in an Aquafuerte ('Etching'), he was granted neither a prestigious foreign language (since his language of origin was brought by poor immigrants and not by governesses) nor the possibility of working from multilingualism. Arlt is anchored in bad translations, and he cannot be the translator. Victoria Ocampo reads originals—not translations—and can be translator and patron of translations. '[My translation] 
"Victoria had a preference for essayists and moral philosophers or writers", John King points out, while "José Bianco had a better eye for imaginative works" (1986: 84). Patricia Willson describes Bianco as a 'Classicist translator' whose motto was 'las traducciones no deben notarse'. Borges, on the other hand, is an 'avant-garde translator', according to Willson. The Argentine critic analyzes Ocampo's translations of Albert Camus, Dylan Thomas, and T. E. Lawrence, and calls Ocampo a 'Romantic translator'. She is a 'Romantic translator' because of the translation strategies that Ocampo used in her own work, but a 'Classicist translator' in editorial choices and strategies that she employed in Sur. Willson borrows the distinction between Classicist and Romantic translators from Borges' 1926 essay "Las dos maneras de traducir" ('Two Ways to Translate'). Sergio Waisman notes in Borges and Translation: The Irreverence of the Periphery that Borges strongly preferred the Classicist stance on translation and that he condemned the Romantic one. It is in "Las dos maneras de traducir" where Borges emphasizes that "classicists are interested in the work of art, not in the artist" (in Waisman 2005: 46). Romantics, on the other hand, "are interested in the artist, they revere the poetic subject, at the cost of the work of art" (in Waisman 2005: 47). After having carefully looked at the corpus of Ocampo's translations, Willson notes that Ocampo always made a choice to translate the literary texts where an 'I' was highly pronounced. Ocampo delegated others to translate for her journal (and later for her homonymous publishing house) those texts that were written in third person. For herself, however, she always chose to translate those texts whose enunciation is in the first person: plays and autobiographical narratives, such as T. E. Lawrence's first person narratives [found in her 338171 T. E. (Lawrence of Arabia)] and his novel The Mint (translated as El troquel), as well as Graham Greene's and Albert Camus' plays.

It is interesting to note that Sur's engagement with Faulkner was not inspired directly by the U. S. , but rather took a 'detoured' route. This critical 'detour', as it were, came from Europe. It was the French translations of the North American author, who would be widely read much later in his career and who would win the Nobel Prize in 1950, that sparked Sur's interest. Thus, Faulkner was introduced to Argentina via France. The Nouvelle Revue Française had published essays on his work as early as 1931. Several translations of his novels and short stories came out from the publishing house Gallimard. Maurice Edgar Coindreau, a Princeton University Professor who was Faulkner's French translator in the 1930s, was instrumental in introducing younger North American authors to a French audience. In 1937, in its $30^{\text {th }}$ issue, Sur included Coindreau's survey of young North American writers. A 
year later, in March 1938, the journal published Coindreau's introduction to John Steinbeck under the title "John Steinbeck, novelista de California" (John Steinbeck, California Novelist'). In August 1939, Sur published an original work of Faulkner's, a short story titled "Dry September" that was translated by Borges as "Septiembreardido". John King points out that in the U. S. , Faulkner's work had been poorly received a decade earlier. It was therefore far-sighted of Sur to publish Faulkner in August 1939, King notes, explaining the circumstances around this important translation.

In the 1930s and 1940s, Borges also translated Edgar Allan Poe, Herman Melville, and the American modernist poet e. e. cummings. Borges' translation of Walt Whitman's Leaves of Grass appeared much later, in 1969. It was around this time that the 'Boom' exploded and Latin American literature started to be known worldwide. Most of the 'Boom' authors were readers of Faulkner. They recognized that their most important literary influences were often introduced to them by Sur. It is interesting to note, however, that although a first translator of Faulkner in Sur, Borges was not overly interested in Faulkner's work. His literary tastes were different. However, the influence of both writers on inter-American literature, through translation and otherwise, turned out to be paramount.

An essay about Faulkner accompanied the first translation of "Dry September" in Sur. It was written by an Argentine intellectual, María Rosa Oliver. Two years later, in 1941, Oliver would be involved in the preparation of the journal's two most important issues: the October 1941 issue ¿Tienen las Américas una historia común? ('Do the Americas have a Common History?') and the December 1941 issue La guerra en América ('The War in America'). As John King points out, María Rosa Oliver lived in the U. S. from 1942 to 1944 and worked in the Office for the Coordination of Inter-American Affairs. This office was set up by Nelson Rockefeller in 1940 to foster ties between economic and cultural programs in Latin America and the U. S. Echoing the political climate of the Good Neighbor Policy, in the two 1941 issues (and throughout the 1940s), Sur confronted the official Argentine policies and openly proclaimed its support for the United States, the Allies, and the concepts of Pan-Americanism and inter-American cultural collaboration.

Lewis Mumford's essay "El arte en los Estados Unidos" ('Art in the United States') and Gorham Munson's "La novella norteamericana de post-guerra" ('The Post-War North American Novel'), which appeared in the third and fourth issues of the journal, respectively, marked the beginning of the long-lasting interest that Sur had in U. S. literature. This interest was accompanied by translation practices, but also, and in slightly larger numbers, by 
essayistic writing. In the fifth issue (1932) appeared "La América del Norte a través de los ojos de su juventud. Notas a la obra de Ernest Hemingway y William Faulkner" ('North America through the Eyes of its Youth: Notes on the Work of Ernest Hemingway and William Faulkner') by Herminia Hallam Hipwell. In addition to excerpts from Waldo Frank's narrative works, the journal also included critical essays about Frank and his own essays about other North American writers, such as "Un gran poeta americano. Introducción a Hart Crane" ('A Great American Poet: Introduction to Hart Crane') that appeared in the $8^{\text {th }}$ issue. Although Frank's presence in the pages of Sur diminished towards the end of the 1930s, the interest in North American literature gradually increased as the 1940s were approaching.

Borges not only worked for Sur as a translator, but he also wrote critical essays about literatures written in English, such as those about GK Chesterton and Mark Twain. On the occasion of the $100^{\text {th }}$ anniversary of Twain's birth, in November 1935, Borges wrote "Una vindicación de Mark Twain" ('A Vindication of Mark Twain'). Sur's 30 ${ }^{\text {th }}$ issue, published in March 1937, contained "Panorama de la actual literature joven norteamericana" ("Panorama of Current Young North American Literature') that Coindreau had sent from Princeton. In this essay, the French professor points to Theodore Dreiser as the major influence of the younger writers who represented what he calls a "proletarian novel". Although not very sympathetic to this type of novel, Coindreau emphasizes Dreiser's influence on John Dos Passos' Manhattan Transfer, for example, as being stronger than that of Sinclair Lewis. Using a sports metaphor, the French critic notes that William Faulkner took the Olympic torch from Sherwood Anderson and is leading his generation of writers into the future. Patricia Willson aptly summarizes Faulkner's unique position in the history of Argentine translation and publishing:

Un caso especial dentro de este grupo de novelistas norteamericanos es William Faulkner, autor que reúne experimentación formal y representación mimética, y en el cual tanto Coindreau como Oliver ven el mayor valor literario. La prueba de ello es que Faulkner es el novelista del grupo que fue traducido por igual en distintas editoriales porteñas: en Santiago Rueda, desde luego, pero también en Sudamericana, Sur, Losada y Emecé. ${ }^{2}$

2. 'A special case among this group of North American novelists is William Faulkner, an author who combines formal experimentation and mimetic representation, and in whom both Coindreau and Oliver see the greatest literary merit. The proof of this is that Faulkner is the only novelist of the group who was translated in several publishing houses in Buenos Aires: in Santiago Rueda, of course, but also in Sudamericana, Sur, Losada and Emecé'. (2004: 254) [My translation] 
In 1938, Sur included an essay that J. Donald Adams wrote in New York in December 1937 titled "La novela en Estados Unidos" ("The Novel in the United States'). The proletarian themes are reiterated in this essay as Adams points out three major tendencies in the North American novel: a) a return to the past b) a proletarian orientation and c) formal preoccupations. That proletarian themes were not of much interest to Sur comes as no surprise. North American literary works with such themes would be published elsewhere in Buenos Aires: at Santiago Rueda, Claridad, and other publishing houses. In the early 1940s, "ya en Sur prevalece la estética antirrealista preconizada por Borges" ('the antirealist aesthetic extolled by Borges already prevails in Sur') (Willson 2004: 254).

The March-April 1944 double issue (113-14) is a case in point. The poetic section of this issue opens with Walt Whitman's poems that were translated by Ricardo Baeza. The section continues with poems by Karl Shapiro, Robert Penn Warren, and Dunsten Thompson. Wallace Stevens and e. e. cummings are translated by Bioy Casares and Borges in collaboration. The narrative section of this issue is introduced by María Acosta's translation of Katherine Anne Porter's "Noon Wine" (translated as 'El vino de mediodía').

Pheng Cheah and Bruce Robbins have coined the term 'cosmopolitics' to refer not to universal reason in disguise, but to a series of political strategies that traverse the borders between the national and the international, the universal and the particular, the local and the global. Displacement and circulation, in various degrees, play a key role in the construction of such strategies. Robbins has stated in this regard that not enough attention has been paid to the different modalities in which intellectuals are being situated while in displacement (1998: 246). My aim here has been to situate Sur's translation practices within the critical revision of inter-Americanism that points, precisely, to its political conditioning and the specificity of its historical circumstances.

As we look at translation and literature of the Americas in the first decade of Sur, we realize that cosmopolitan mediation would be impossible without the work of translators and other cultural brokers. And as we study the importance of Victoria Ocampo to Translation Studies, we highlight the lifelong importance of translation to Victoria Ocampo and to her significant engagement in the inter-American cultural enterprise. This makes us realize that these complex processes would be impossible without the agents and carriers of cultural transmission. Literature of the Americas and inter-American relations, an important component of Ocampo's cosmopolitan reaching out to the world, would not have been the same without the collaborative contribution of editors and translators affiliated with Sur. 


\section{Bibliography}

BRODzKI, Bella. (1999) "History, Cultural Memory, and the Tasks of Translation in T. Obinkaram Echewa's I Saw the Sky Catch Fire." PMLA 114, pp. 207-221. KING, John. (1986) Sur: A Study of the Argentine Literary Journal and its Role in the Development of a Culture 1931-1970. Cambridge: Cambridge UP.

LARKosh, Christopher. (2002) "Translating Woman: Victoria Ocampo and the Empires of Foreign Fascination.” In: Tymoczko, Maria \& Edwin Gentzler (eds.) 2002. Translation and Power. Amherst: University of Massachussetts Press, pp. 99-121.

Majstorovic, Gorica. (2005) “An American Place: Victoria Ocampo's Editorial Politics, the Foundation ofSur, and Hemispheric Alliances". In: Henseler, Christine \& Alejandro Herrero-Olaizola (eds.) 2005 Matters of the Market: Texts \& Contexts in Spanish and Latin American Literature. Arizona Journal of Hispanic Cultural Studies. Volume 9, pp. 171-180.

OCAMPO, Victoria. (1976) "Un asunto de suma importancia: La traducción." Sur: Problemas de la Traducción 338-339, pp. 15-19.

PAZ, Octavio. (1962) "De Octavio Paz." Testimonios sobre Victoria Ocampo. Buenos Aires. 279-280.

RobBins, Bruce. (1998) "Comparative Cosmopolitanisms." In: Cheah, Pheng \& Bruce Robbins (eds. ) 1998. Cosmopolitics: Thinking and Feeling beyond the Nation. Minneapolis \& London: University of Minnesota Press, pp. 246-265.

SADOWSKI-SMITH, Claudia \& Claire FOX. (2004) "Theorizing the Hemisphere: Inter-Americas Work at the Intersection of American, Canadian, and Latin American Studies." Comparative American Studies 2: 1, pp. 5-38.

SARLO, Beatriz. (1993) "Modernity and Cultural Mixture: The Case of Buenos Aires.” In: King, John; Ana M. López \& Manuel Alvarado (eds. ) 1993. Mediating Two Worlds: Cinematic Encounters in the Americas. London: British Film Institute, pp. 164-174.

SARLO, Beatriz. (1996) "Oralidad y lenguas extranjeras. El conflicto en la literatura argentina durante el primer tercio del siglo XX." Orbistertius: revista de teoría y crítica literaria 1: 1, pp. 167-178.

SARLO, Beatriz. (1998) "Victoria Ocampo o el amor de la cita." In: La máquina cultural: maestras, traductores y vanguardistas. Buenos Aires: Ariel, pp. 93-195.

Various authors. 1976. Sur. Nendeln, Liechtenstein: Kraus Reprint.

WAISMAN, Sergio. (2005) Borges and Translation: The Irreverence of the Periphery. Lewisburg: Bucknell UP.

WAISMAn, Sergio. (2010-2011) "Foundational Scenes of Translation." E. I. A. L. Estudios Interdisciplinarios de América Latina y el Caribe. 21: 1, pp. 1-13.

Willson, Patricia. (2004) La constelación del sur: traductores y traducciones en la literatura argentina del siglo XX. Buenos Aires: Siglo Veintiuno Editores. 


\section{BIONOTE / NOTA BIOGRÁFICA}

Gorica Majstorovic is Associate Professor of Latin American and World Literature at The Richard Stockton College of New Jersey, U. S. A. She studied Hispanic literatures at the University of Belgrade, Serbia (former Yugoslavia) and earned her Ph. D. at New York University. Among her publications are "An American Place: Victoria Ocampo's Editorial Politics, the Foundation of Sur, and Hemispheric Alliances" (Arizona Journal of Hispanic Cultural Studies, Fall 2005), "From Argentina to Spain and North Africa: Travel and Translation in Roberto Arlt" (Iberoamericana. España. Latinoamérica. Portugal, Spring 2006), and other articles, in forthcoming books Alfonso Reyes. Nuevas Lecturas, and Muy Machos: Representations of Argentine Masculinities. Professor Majstorovic is also a translator, of Stephen Dunn, CristinaPeri-Rossi, and other writers. She is currently writing a book titled Crossroads.

Gorica Majstorovic es profesora universitaria de literatura latinoamericana y mundial en The Richard Stockton College of New Jersey (Estados Unidos). Estudió Filología Hispánica en la Universidad de Belgrado, Serbia (antigua Yugoslavia) y se doctoró en la New York University. Entre sus publicaciones se encuentran "An American Place: Victoria Ocampo's Editorial Politics, the Foundation of Sur, and Hemispheric Alliances" (Arizona Journal of Hispanic Cultural Studies, 2005), "From Argentina to Spain and North Africa: Travel and Translation in Roberto Arlt" (Iberoamericana. España. Latinoamérica. Portugal 2006) y otros artículos, en libros de próxima publicación, Alfonso Reyes. Nuevas Lecturas, y Muy Machos: Representations of Argentine Masculinities. La profesora Majstorovic es también traductora, con versiones de Stephen Dunn, Cristina Peri-Rossi y otros escritores. Actualmente está escribiendo un libro titulado Crossroads. 